Copyright (C) 2016 by Academic Publishing House Researcher

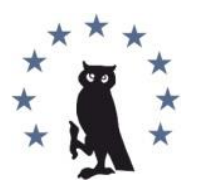

Published in the Russian Federation

European Researcher

Has been issued since 2010.

ISSN 2219-8229

E-ISSN 2224-0136

Vol. 106, Is. 5, pp. 252-270, 2016

DOI: 10.13187/er.2016.106.252

www.erjournal.ru

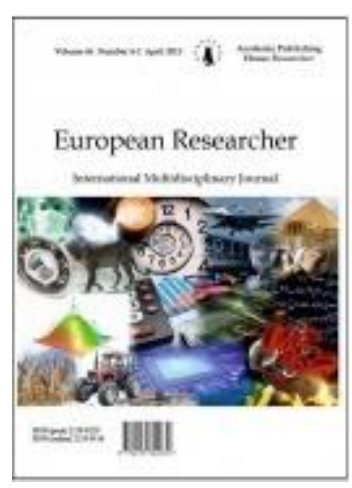

UDC 33

\title{
From Concept of the Region to Regional Image of Montenegro
}

\author{
${ }^{1}$ Goran Rajović \\ ${ }^{2}$ Jelisavka Bulatović
}

\begin{abstract}
${ }^{1}$ International Network Center for Fundamental and Applied Research, Russian Federation E-mail address: dkgoran.rajovic@gmail.com

${ }^{2}$ College of Textile Design, Technology and Management, Belgrade, Serbia

E-mail address: jelisavka.bulatovic@gmail.com
\end{abstract}

\begin{abstract}
The focus of work is the understanding of the problems of regional development in recent times is becoming increasingly important socio - economic issue. The paper seeks to argue that the context and Regional Development provides an opportunity to resolve the paradox of development interpreted by many researchers. Issues of Regional Development of Montenegro for more than half a century did not have adequate theoretical or practical foundation. New current models of economic growth and development were based on sector priorities and policies, the short and medium term objectives. In order to slow down the aging process of the population of Montenegro and mitigate its effects, it is necessary to increase the birth rate, which would encourage the gradual rejuvenation of the population. The second group of measures relates to immigration, and the third to increase youth employment in order to prevent any more numerous emigrations. The problem employment/unemployment is one of the most socio - economic problems in Montenegro. Therefore, in the management regional development policy at EU level, special importance is given to finding adequate mechanisms and instruments that will contribute to the better functioning of labor markets, and thus to a more balanced regional development. In Montenegro, it is necessary to elaborate a new concept, a comprehensive regional development, which will be based on demographic, natural, economic and socio-cultural resources.

Keywords: Montenegro, regions, regional development, demographic indicators, indicators of socio-economic development (employment and unemployment).

\section{Introduction considerations}

The regional dimension of development has become the subject of scientific and technical research, imposed processes and problems of disparities in the use, organization and planning area [1]. A crucial element in changing the concept of the region (from formal to functional) was in imposing and treating development as the cause of changes in space and its functional differentiation [2]. The evolution of scientific thought on regions (Rogić [3]; Thompson [4]; Foucalcut [5]; Searle [6]; Hettne [7]; Zaretsky [8]; Mansfield and Milner [9]; Castells [10]; Milenković [11]; Lupel [12]; Todd [13]; Grad and Rojo [14]; Harrison [15]; Ruano - Barbalan [16]; Nojman [17]; Turen [18]; Jonas [19]; Agnew [20]; Jonas [21], increasingly affirm sits development dimension and the possibility of entering into consideration the dynamism structural socio-economic processes in the
\end{abstract}


context of cause and effect relationships. This region is becoming a complex system of interactive performance society economies in time and space [1]. A special are contribution to the explanation of regional differences and specificities of geo-space given by the geographical science.

From July 4th to July 10th 2010 the International Geography Union (IGU) Commission on "Globalization, marginalization, and regional and local response" (Co8-27) gathered during an itinerant conference held both in Graz (Austria) and Fribourg (Switzerland). Given the location of the conference, it was organized around the theme "Mountain Areas and Globalization" (hereafter called "the Conference"). Six specific topics were proposed to the participants: regional policies and strategies, ageing societies: ghettoization in mountain areas, agricultural niche productions and regional labels, mountain regions and new technologies, biodiversity, natural hazards and human response. In the end, most papers were dealing with regional policies and strategies, probably because this topic was broader and more encompassing. After the conference, it was proposed to the participants to contribute to the production of a research note that would summarize the main collective findings raised from the discussion during the conference [22].

The term regions can be defined in different ways. Under it may understand narrower or broader territorial units within a particular state, but also the area whose boundaries extend over the territories of two or more States do not necessarily coincide with national boundaries. Regions, like all other human societies, constantly define and redefine, given that the number of participants in the study was never the same [23]. According to Klemenčic [24] concludes that the region is part of the land area which is characterized by certain characteristics (physical, economic, political ...), which make it unique and different from other areas. Thus, the region may make the space with homogeneous landscape or functional characteristics or heterogeneous area which accumulated a variety of features make the whole different from neighboring regions. This level of defining the region of synthetic character and is based on the principles of respect of the whole complex range of factors and far better reflect the complex geographic reality.

According to Fedajev and Nikolić [25] referring to research Ilić-Gasmi [26], Međak and Majstorovic [27] and Lajh [28] indicate that the in the period after World War II is characterized by the appearance of a large number of regional economic integrations. Certainly one of the most important and most successful is the European Union (EU). The basics of its creation, lies in the aspirations to overcome historical rivalries, especially France and Germany, along with encouraging economic growth and development of Member States. The idea of creating and developing the unique EU regional policy is dating from the very beginning of European integration. Namely, even in the Preamble of the Treaty of Rome the 1958 was stated that "the state - members of the European Union seek to ensure harmonious development by reducing differences in the degree of development of certain regions and the backwardness of less privileged regions. Whereas, the regional policy of the European Union implies not only a regional development in the narrow sense, but also attempts to make connections at the Union level by reducing the existing differences in development of certain regions. Therefore, EU regional policy is often called the cohesion policy. It is not a substitute for regional policies of member states, but their amendment. It is the reallocation policy of major importance in almost exclusively regulatory project of European integration.

Table 1. Scientific approaches and their main characteristics

\begin{tabular}{|c|c|c|c|c|}
\hline Approaches & Epistemology & Ontology & Metodología & Mark \\
\hline Empiric & $\begin{array}{c}\text { Personal } \\
\text { Experiences }\end{array}$ & $\begin{array}{c}\text { What they see, that } \\
\text { exists }\end{array}$ & Proving facts & Description \\
\hline Positivist & $\begin{array}{c}\text { Objective } \\
\text { experience }\end{array}$ & $\begin{array}{c}\text { Which can be } \\
\text { verified, that exists }\end{array}$ & $\begin{array}{c}\text { Verification, } \\
\text { scientific method }\end{array}$ & Explanation \\
\hline Humanistic & $\begin{array}{c}\text { Subjective } \\
\text { experience }\end{array}$ & $\begin{array}{c}\text { What it is accepted } \\
\text { that exists } \\
\text { The }\end{array}$ & $\begin{array}{c}\text { Personal } \\
\text { interpretation of } \\
\text { the world }\end{array}$ & Understanding \\
\hline structuralism & Ideas, & $\begin{array}{c}\text { Structures } \\
\text { (hidden) }\end{array}$ & $\begin{array}{c}\text { Construction, } \\
\text { theory of real } \\
\text { structures }\end{array}$ & Detection \\
\hline
\end{tabular}

Source: Boesch [29]. 
The principle of physiognomic homogenization in the past had greater application and comes from so-called deterministic phase of development of geographical science, when it was considered by Ruppert et al [30] that natural factors have a decisive influence on the territory and the formation of the region, while the influence of the man considered ancillary. In accordance with a deterministic approach to regionalization, the border regions were determined by natural boundaries (rivers, mountains ...). Over time, the approach to regionalization has been changing, and more meaning gave anthropogenic influences. So morphogenetic approach are respecting the natural factors, increasingly stresses the need for insight into the complex social factors that affect the space and the creation of the region. Consequently, by Antic Slukan [31] here are the boundaries of the region were certain stories all social factors - population, economy, property ... Both of these approaches-deterministic and morphogenetic-differed space so as to share it physiognomic and homogeneous regions. Thus, as pointed out Rogić [32] target geographical regionalization is not the division of space, rather than explaining objectively existing regional spatial differentiation, and the criterion of allocation cannot be limited only to one group of spatial components of the complex.

Thus the appearing per Antić Slukan [31] called functional regionalization, which distinguish the region on the basis of their complex functional connections, and not solely on the basis of their homogenous landscape characteristics. So that the region can do and heterogeneous space are that is connected to the effect of one factor or more, as a rule, the gravitational force of urban centers (the center-periphery), or some other social interest. In this way were formed regions that make up the functional unity. Certainly, all these principles of regionalization, except geographical factors, more or less, have always acted and external factors, particularly the economic and political interests, who regularly acted as a corrective geographical regionalization of the area, establishing the region in accordance with the current social context.

According to Piha [33] depending on the criteria for determining the (geographic, economic, social, political ...), or the purpose for which serve regions can be natural, demographic, economic, social, administrative, nodal... To determine the borders of the region there are several criteria: administrative, to social cohesion, according to the directions and intensity of economic development, communications, traditions, functional connectivity, urban gravitating area... Väyrynen [34] rightly concludes that regions as entities that appear and disappear in the historical process in parallel with transformations in the economy, politics and culture or to highlight Neumann [23] to the different definitions and analyzes formation region can be divided into two general approaches: the first could be defined as access from the inside-out approach which emphasizes the processes of cultural integration (inter alia the issue of regional identity ...); the other is called external access, respectively, from the outside - in approach that focuses on geopolitics.

Table 2. Comparison of two theoretical frameworks

\begin{tabular}{|c|c|}
\hline Traditional regional economy & "New Economic Geography" \\
\hline Constant returns & Ascending yields \\
\hline Perfect competition & Imperfect competition \\
\hline The unequal distribution of resources & Endogenous agglomeration process \\
\hline The existence of a borders & Transport costs \\
\hline The statistical equilibrium in the long term & Evolutionary (dynamic) balance \\
\hline
\end{tabular}

Source: Fujita [35]

In Table 2 was performed illustrative comparison of theoretical assumptions of the traditional school and the "new economic geography". The statistical services of the candidate countries as emphasized Stojkov [36] for admission to the European Union have reached a 1997 agreement with the Statistical Office of the European Communities in Luxembourg (EUROSTAT) that the overall orientation with respect to the administrative - territorial organization m leads over NUTS territorial system. This one is established nomenclature NUTS 5 according to population, or the size of the territorial units. According to the current criteria and 
statistical territorial units according to EU standards are: NUTS 1: 3 - 7 million inhabitants (state or federal units), NUTS 2: 800.000 to 3 million people (macro-region) and NUTS 3: 150.000 to 800.000 inhabitants (county or district), NUTS 4: 10.000 - 150.000 inhabitants (urban municipalities) NUTS 5: fewer than 10.000 inhabitants (rural municipality or village). Adapted countries NUTS system facilitates admission to the European Union and provides access to structural funds to finance the program, which proved important in the countries of Central and Eastern Europe.

What is significant is that the Territorial Agenda introduced mandatory implementation of an integrated strategic territorial approach, i.e. implementation of integral planning and management for all actors in EU, especially local and regional actors, within limits set out at Pan-European and national levels. The establishment of the integral approach to guiding and managing development of the European Union was also supported by the revised European Union strategy for sustainable development. The following were categorized as territorial priorities in scope of the EU development process: strengthening polycentric development and innovation through networking urban regions and cities; establishing new forms of partnership and territorial management in developing urban and rural areas, predominantly at the level of functional urban areas; promoting regional competition and innovation clusters with the aim of stimulating development and specialization of peripheral and underdeveloped European regions; strengthening and spreading trans-European transport corridors, improving technical (especially energy) infrastructure, and decentralizing services of public interest; promoting Trans-European risk management, including climate change impacts and new forms of managing protection of areas, etc.; strengthening environmental structures and cultural resources as development potential, especially in regions which lag behind in development and in environmentally and culturally sensitive areas [37].

According to Milanović et al [38] when talking about regionalization of Montenegro, although it was not officially adopted, the Republic is usually divided into three major regions: North (or mountain), Central and South (or Coastal). Of the 21 municipalities, the North region belongs to 11 municipalities (Andrijevica, Berane, Bijelo Polje, Kolašin, Mojkovac, Plav, Plužine, Pljevlja, Rožaje, Šavnik and Žabljak); Central includes 4 municipalities (Cetinje, Danilovgrad, Nikšić and Podgorica), while in the Southern Region 6 municipalities(Bar, Budva, Herceg Novi, Kotor, Tivat and Ulcinj). Regional development in Montenegro, over many decades is not viewed as an integral part of the overall socio-economic development, it is the issue of regional development was marginalized and analyzed as a separate and not particularly important aspect of the overall development. Ignored the fact that the development has its own specific spatial dimensions are that defining of institutional development mechanisms regionally neutral. Regional differences have been observed mainly in terms of level of development, so that they neglected their economic development, social, community and especially demographic characteristics.

Basically, that some region was decorated, it is necessary that it meets at least four groups of conditions: geographical and historical (clearly separate "natural" geographical unit which is separately formed over a long historical period), economic and social (economic provision of netting wider areas in order to rationalize production and raise the standards and quality of human life not only in the region but also in the community will which he belongs), legal-political (the democratically expressed will for political self - government carried out with respect for the Constitution and the laws provided for procedures ) cultural and the spiritual (the pursuit of a specific affirmation of cultural identity, which is primarily expressed through respect for multiculturalism) [39].

The aim of regional policy is to create economically strong, competitive regions which will be able to integrate into the global economy. The European Union, as well as some other organizations (such as the OECD, World Bank...), continue to emphasize the importance of the region for economic development at national and international level. The objectives of the regional policy do not change, but the strategies to achieve them have changed - traditional approach to regional policy that is primarily based on redistribution of wealth between rich and poor regions and a sector approach, all the more to give way to the principle of strengthening internal and external potential of the region and multispectral approach. 
The paper will therefore analyze: a) regional development problems; b) demographic trends (2003-2011)*; c) employment and unemployment as important indicators of socio-economic development. "The applicable legal regulations and laws in Montenegro do not define the term region as a geopolitical entity. In this sense, this work date's region solely represents the spatial economic or statistical unit, which does not have a separate organization and institution. Thus, the concept of region implies a certain set of local governments that do not correspond to the definition used by the European Union, where the region is defined as an economic region" [38].

\section{Methodology}

Regional development regardless of how and from which theoretical perspective the problem is approached is to improve the quality of life of people. This issue is very complex because it depends on a number of objective and subjective factors, the characteristics of the regions of Montenegro as well as the characteristics of their physical, economic, social, cultural environment [40, 41]. Every human being has the right to good, decent and wealthy living. In other words, we want to have everything we need, we want to be healthy and respected; we want to love and be loved. Another factor important for complacency in one's life is the ability to undertake actions which result in happiness, pleasure or satisfaction. All this influences the level and the quality of our lives. Therefore, the goal of human existence is to improve living conditions, both in the material, social and spiritual realm and in the ecological dimension. The main objective of all countries should be to ensure the well-being of their citizens. Contemporary population policy is one of the instruments. It influences the creation of population processes indirectly through the utilization of specific instruments of social policy (including: family and housing policy, education, healthcare, social security, employment) and economic policy, specific for the required course of said processes [42]. The authors of this paper discuss the regional-geographic basis Montenegro, taking into account the geographical determinants of study. "Historically it is possible to identify several theoretical fields which deal with issues of regional development. One concerns access to the classical theory of economic development, which refers to works created during the 5os and $60 \mathrm{~s}$ of the last century who have developed a number of interesting ideas about the sources of regional development and the interrelationship of regional development and regional inequalities. The second area is based on models of economic development, the well-known neo-classical model of development and recently developed endogenous growth models [43]. The third area deals with models of new economic geography. It's about a young theoretical direction but that in a short time significantly gained in popularity (One of the most important authors in the field of new economic geography, Paul Krugman, who for his theoretical contribution was awarded the Nobel rewards in Economics in 2008). Krugman of the New Economic Geography says: "New Economic Geography ... would the best be described as a genre: style of economic analysis which tries to explain the spatial structure of the economy using certain technical tricks to create models which are present increasing returns and market-labeled monopolistic competition " [43, 44]. Similarly, Fujita and Mori [45] point out that "... the new economic geography only analytical framework based on an overall balance in which the spatial distribution region explicitly defined mechanisms based on market mechanisms...". The whole information volume in this article was obtained through specific methods for the selective research, respecting all its stages from the methodological point of view: identification of the researched issue, research framework delimitation, information collection, data processing, analysis and interpretation drawing up the conclusions. Research also played an important role in the article, which consisted, on one hand, in the identification of other studies and articles on the same subject, and in the processing of some statistic data, on the other hand. Hence, the information sources used can be classified into governmental sources (statistic, ministerial and from research institutes), and into non-governmental sources (independent publications) [46].

\section{Analysis and Discussion}

The issue of regional development more than half a century did not have adequate theoretical or practical foundation. New current models of economic growth and development were based on sector priorities and policies, the short and medium term objectives.

\footnotetext{
* Demographic trends in the period 1921 - 2003 year, was already the subject of interest Milanović et al [38]
} 
According to Rosić and Veselinović [47] in the period of formation of industrial capitalism, which was based on the concept of "laser faire" in the field of production and exchange of goods until the Second World War, the need for management of regional issues were ignored in the economy and we can say in geographical science. In the opinion of the then researchers during the second half of the nineteenth century until the thirties of the twentieth century, the role of markets was essential in eliminating the imbalance of all I did not need significant state intervention, it is a mechanism of the market and the price automatically establish the territorial balance. In parallel with the maturing of ideas on the use of state intervention in the capitalist economy, per Tiosavljevic [48] appear and the first theoretical reflections on regional development. For this reason it was formulated and regional science as a separate discipline and research framework for complex spatial differences among various economic segments within individual national economies.

The history of the institutional roots of regional science in Central and Eastern Europe (CEE) is deeply anchored in the process of radical changes undergone by the former communist countries in the 1990s. The melting of the „iron curtain"e not only triggered the reshaping of Europe and its regions but also created the favorable circumstances for the creation and revitalization of the national sections of the European Regional Science Association (ERSA) in this part of Europe. At present ERSA - one of the supranational associations of the Regional Science Association International (RSAI) - counts 19 active associations (usually named „sections ${ }^{\mathrm{ec}}$ ), out of which 6 are established in the aforementioned countries. Their successful development made ERSA and RSAI entrust them with the organizing of noteworthy, large-scale events such as the ERSA congresses [49].

According to Constantin [49] referring to the research Constantin [50] and Constantin [51] suggests that at the same time the growing participation of East European regional scientists in important regional science meetings enriched the approaches of the classical topics with fresh perspectives, specific to the transition economies and also entailed the emergence of new issues, reflecting the phenomena and concerns associated with regional development in their countries. The subsequent EU enlargement put an even stronger emphasis on regional topics related research, pointing to the new perspectives for convergence/divergence in regional growth, new location and specialization patterns, endogenous regional development the spatial dimension of environmental sustainability.

In a speech on Globalizing Cities and Regions - Rethinking the Urban and Regional Policy Agenda' held on 22 January 2007, OECD Secretary - General ANGEL GURRÍA has phrased it this way: "Regional development must be about wealth creation, and upgrading regional assets, not just a redistribution policy. It is about building place-based assets and potential that will attract business investment and strengthen local firms already in the region. Where once we focused on national systems of innovation are now we must focus on regional systems of innovation as well. This doesn't mean a narrow approach based on so-called high-tech sectors. It means focusing on innovation in all sectors and spheres of activity. Tourism, crafts and food can all be successful activities which generate regional wealth. And they can all be innovative, state of the art [52]. To achieve regional innovation it is important to improve physical infrastructure, education and healthcare, the environment for start-ups and growth of small and midsize businesses, the sharing and spreading of knowledge, and the availability of support services...Universities and technical institutes can help companies, especially small and midsize enterprises, solve technical, managerial or marketing problems, as well as helping to provide skilled people and access to lifelong learning. Moreover, local networks of entrepreneurs and supporting service are industries represent an important means of knowledge-sharing in a community" [52].

Regional development, i.e., regional planning in Montenegro, has been sidelined for too long, never in the hierarchy of development objectives have the place it deserves, constantly the repressed the problems of regional development, unsynchronized measures are short-term amortized conflicts (for example by encouraging the development of certain disadvantaged areas). Historically (since the Second World War to the present day) there were several periods with specific characteristics in terms of the type of regional strategies and policies. According to Janičic et al [53] the regional development and encouraging the under-developed areas of the former Yugoslavia after the Second World War, mainly driven by the Federation and can be viewed through three stages: the period up to 1965 - the main sources of financing General Investment Fund and the Federal budget, the period from 1965 to 1974 - the 
Act on the federation to lend the economic development of economically insufficiently developed republics and regions, the Fund has taken these jobs and the period from 1974 to 1990 - the Fund was transformed into the Federation Fund for lending to quicker development of the underdeveloped republics and autonomous provinces. The dissolution of Yugoslavia, all the republics as independent states continued to independently pursue a policy of regional development. According to Čavrak [54] in the longest period of the applied theory of equality with the aim polycentric development based on industrialization, i.e. creating and locating large industrial plants as bearers of development of individual regions. This has created unequal economic structure in non-resistant to transitional crisis nineties with major negative consequences of the decline in production, employment and income in those regions that have been developing with greater participation of large industrial plants.

Our research evidence based on similar studies Jakopin and Perišić [55] indicates that transition processes since 2000 in Montenegro just further intensified and multiplied the negative regional effects. At the same time, developed centers (coastal and central) comes to the excessive concentration of population and economy, which produces negative results in the economic, social, spatial and ecological sphere. It is a condition tends depopulation of the northern region, and increased social costs due to the high concentration of population in coastal and central region of Montenegro. "The development of the northern region also brings limitations and in terms of social development (through limited access to institutions and services) and increased risk of unsustainable use of natural resources (primarily forest). The northern region, which accounts for slightly more than half of Montenegrin territory, characterized by: a share of only $18 \%$ of GDP (at the beginning of 1990, 25.5\%); in the northern region has less than one-third of the total population; the poverty rate is significantly higher than the average for the Republic - 19.3\%; Transportation (and other) infrastructure, especially in rural areas" [38].

Past experience and current trends in regional development indicate that the territorial deformation of Regional Development consequence not only of defects applied regional development policy, but rather, absence of systemic and institutional regulatory mechanisms. According to Vujović [56] the European Union has developed various forms of regional policy, which is characterized by two core values: Solidarity balancing regional development through various forms of assistance to insufficient (below average) developed regions and cohesion positive benefits by the richer for those who are poorer environment.

An important indicator of regional development as demographic trends on is which to a large extent influenced by the living conditions. The degree of development is best illustrated by an unbalanced spatial distribution of the population. Demographic variables and socio-economic status may cause differences in objective living conditions and the manner in which an individual experiences and assess the quality of your life. The impact of demographic variables on the quality of life testing in numerous studies, which showed different patterns of association in different cultures (Andrews and Withey [57], Watson et al [58], Van Oudenhoven and Willemsen [59], Wqaston and Klark [6o], Ruff et al [61], Wahl et al [62], Lima and Novo [63], Lučev and Tadinac [64]). Society may differ according to the expectations and standards relating to the standard of living and level of satisfaction and happiness, as well as to the objective conditions of life that are associated with certain demographic characteristics [64].

Table 3 shows the distribution of the number, change, growth rates, population density and the average age of the population in the period from 2003-2011. According to the Ministry of Economy of the Government of Montenegro [65] more than $50 \%$ of the national territory of the North region of Montenegro is inhabited by less than a third of the total population, while nearly a quarter of the population inhabits only slightly more than $10 \%$ of the territory of the coastal region. In the inter-census period is noticeable decrease in the population of the Northern region (- 7.2\%), while in the central and coastal region marked an increase of $5.9 \%$ and $3.7 \%$. These changes are caused by the natural movement of the population, as well as a pronounced migration flows directed from north to central and coastal part of the country. 
Table 3. Basic demographic indicators in Montenegro

\begin{tabular}{|c|c|c|c|c|c|c|c|}
\hline Regions & $\begin{array}{c}\text { Population } \\
2003\end{array}$ & $\begin{array}{c}\text { Population } \\
2011\end{array}$ & $\begin{array}{c}\text { Change } \\
2011 / \text { o3 }\end{array}$ & $\begin{array}{c}\text { Rate of } \\
\text { growth } \\
2011 / \text { o3(\%) }\end{array}$ & $\begin{array}{c}\text { Population } \\
\%\end{array}$ & $\begin{array}{c}\text { Density of } \\
\text { population }\end{array}$ & $\begin{array}{c}\text { Average } \\
\text { age of the } \\
\text { population }\end{array}$ \\
\hline Northern & 191.610 & 177.837 & -13.773 & -7.2 & 28.7 & 24.35 & 37.3 \\
\hline Central & 277.279 & 293.509 & 16.230 & 5.9 & 47.3 & 59.69 & 36.6 \\
\hline Maritime & 143.378 & 148.683 & 5.305 & 3.7 & 24.0 & 93.45 & 38.4 \\
\hline
\end{tabular}

Source: Ministry of Economy Government of Montenegro [65].

As the data in Table 3 on one side, the population in the northern region is reduced in period from 2003 - the year 2011 with 191.619 to 177.837 inhabitants, i.e. 13.773 , or a rate of $-7.2 \%$, on the other side of the population in the coastal region has increased by 5.305 people, or from 143.378 to 148.683 , or by $3.7 \%$, while in the Central region recorded a population increase of 16.230, or from 277.279 to 293.509 , or by $5.9 \%$. In addition, the average density ranged from $24.35 \mathrm{in} / \mathrm{km}^{2}$ in the North region, $59.69 \mathrm{in} / \mathrm{km}^{2}$ in the central to $93.45 \mathrm{in} / \mathrm{km}^{2}$ in the coastal region. Judging by presented analytical indicators, population of Montenegro marks the threshold of demographic aging, the demographic age and deep demographic age. It is obvious that to the fore coming demographic momentum (demographic inertia), which determines the projected changes in the age structure [66]. To be reconvened "circulars vicious" are depopulation (partial and total) and changes in the composition of age in the direction of further aging of the population. The average age of the population in the Central region was 36.6, 37.3 in the North and the Southern 38.4. How many aging population engulfed Europe, indicated by the fact that even the country with the lowest Uses old ages 65 and above year-Turkey are in the process of aging [67]. As for the demographic consequences, aging acts according to Chesnais [68]: slowing the rate of population growth, decreasing birth rate, increasing the overall mortality rate, reducing migration of the population, causing a further deterioration in the structure of population by age and sex, influence to the aging of the working population contingent. In addition to demographics there are numerous social, economic, political and other consequences of future demographic changes.

Table 4. Population growth by regions (2003-2011)

\begin{tabular}{|c|c|c|}
\hline Geospace & Natural increase (2003-2011) & Migration balance (2003-2011) $^{*}$ \\
\hline Northern & 3.388 & -17.161 \\
\hline Central & 11.571 & 4.659 \\
\hline Maritime & 3.237 & 2.068 \\
\hline Montenegro & 18.196 & -10.434 \\
\hline
\end{tabular}

Source: Ministry of Economy Government of Montenegro [65].

In the reporting period 2003-2011, there was a positive population growth in all three regions (Maritime - 3237, North - 3.388, Central - 11.571). Migration balance population is the difference between the number of allocated and the number of settlers in a given period. Migration balance at the level of Montenegro in the period 2003 - 2011 shows a negative trend and amounted to 10.433, by region: North - 17.161, Maritime 2.068, 4.659 Central. According to data of the Statistical Office of Montenegro - Monstat [69] the total number of the population moved around within Montenegro in 2013 amounted to 4.374 inhabitants; the majority of the population are women with $55.7 \%$ or 2.438 , while men make up $44.3 \%$ of the total, or 1.936 inhabitants. Women aged o to 34 and over 65 and over will be moving more than men the same age. The biggest difference is in the age group of 20 to 24 years and amounts to 276; Men are the majority in the age groups from 35 to 64 years. The biggest difference compared to women in the age group of 55 to 59 years and is 37 .

\footnotetext{
* The migration balance is obtained based on the difference in population between the two censuses, and natural increase for the period from 2003 - 2011.
} 
Table 5. Working age population (15-64 years) by region

\begin{tabular}{|c|c|c|c|c|c|c|}
\hline \multirow{3}{*}{$\begin{array}{l}\text { Geospace } \\
\text { Northern }\end{array}$} & \multicolumn{2}{|c|}{2003} & \multicolumn{2}{|c|}{2011} & \multirow{2}{*}{\multicolumn{2}{|c|}{$\begin{array}{l}\text { Change 2011/2003 } \\
\text { Rate of growth (\%) }\end{array}$}} \\
\hline & Number & $\begin{array}{c}\text { Participation } \\
\text { (\%) }\end{array}$ & Number & $\begin{array}{c}\text { Participation } \\
\text { (\%) }\end{array}$ & & \\
\hline & 123.191 & 30.87 & 117.647 & 27.90 & -5.544 & -4.5 \\
\hline Central & 186.086 & 46.63 & 201.695 & 47.83 & 15.609 & 8.4 \\
\hline Maritime & 89.772 & 22.50 & 102.351 & 24.27 & 12.579 & 14.0 \\
\hline Montenegro & 399.049 & 100.00 & 421.93 & 100.00 & 22.644 & 5.7 \\
\hline
\end{tabular}

Source: Ministry of Economy Government of Montenegro [65] .

Working age population in the period 2003 - 2011 at the level of Montenegro increased by 22.644 inhabitants which represents a growth rate of $5.7 \%$. Broken down by regions, growth was recorded in the Central (8.4\%) and the Southern region (14.0\%), while the number of working-age population decreased in the North region $(-4.7 \%)$. Such a trend may be a limiting factor for the development of the North region. At this point it is important to point out the research Stojiljković [6o] that a number of problems during the nineties characterized the economy of Montenegro, has reduced the number of the employed population. Nineties the last century - crisis, sanctions, wars and the informal sector have influenced the radical changes in the functioning of the state. At the beginning of the new millennium, there has been a transition, which included privatization and big layoffs, which only worsened the ratio of the number of employees, which was getting smaller, and the number of pensioners, whose number is ever increasing. Progressive reduction of employees and pensioners increase significantly impedes the functioning of the pension system, based on the transfer of contributions to pensions. The deficit incurred as a consequence of its available budget funds and increase the number of pensioners when outnumber the baby boomers who were employed for a long time become entitled to a pension will only intensify the problem. Population projections show clearly that the numerically larger baby boom generation affect "outflows" the significant size of the working age population after 2013, and that this generation is not fiction but actually significantly more numerous groups. Informing the public, as well as the specific preparation of this sudden transition is necessary, in order to avoid dramatic consequences. The problem of a large number of pensioners to be addressed by is integrating measures. A low fertility rate, which is actually the cause of increasing the share of pensioners in the total population also not be considered in isolation, but must be an awareness of a cause-and-effect relationship between these phenomena.

Table 6. Socio-economic differences at the level of three regions *

\begin{tabular}{|c|c|c|c|}
\hline Indicator & \multicolumn{3}{|c|}{ Regions } \\
\cline { 2 - 4 } & Minimum & Maximum & Span \\
\hline $\begin{array}{c}\text { Total income of the region per } \\
\text { capita (in €) in 2013 }\end{array}$ & 1.031 .5 & 2.233 .8 & 5.70 \\
\hline $\begin{array}{c}\text { Budget revenues of the region } \\
\text { (own and seconded to law)per } \\
\text { capita in € in 2013 }\end{array}$ & 100.46 & 572.99 & 1.87 \\
\hline $\begin{array}{c}\text { Average unemployment rate at } \\
\text { the regional level in 2013. }\end{array}$ & $11.7 \%$ & $21.9 \%$ & 1.27 \\
\hline $\begin{array}{c}\text { Share of educated population } \\
\text { in the total population aged 15 } \\
\text { to 64 years }\end{array}$ & $71 \%$ & $90 \%$ & 1.14 \\
\hline $\begin{array}{c}\text { General population movement } \\
\text { in 2011. (2003=100) }\end{array}$ & 92.8 & 105.8 & 5 \\
\hline
\end{tabular}

Source: Ministry of Economy Government of Montenegro [65].

\footnotetext{
${ }^{*}$ Individuals with high school, college and university graduates in the total population aged 15 years and over.
} 
In addition to population trends, important indicators of socio - economic development in Montenegro, employment and unemployment, which have a strong regional dimension? The problem is particularly acute in the northern region of Montenegro. The decline in economic activity in the last two decades, depopulation of rural areas, migration of population from the north of Montenegro in Central and Coastal Region, affected the deepening of the problem and its difficult resolution. In the Northern region, the number of unemployed persons at the end of 2013 was 12.810 , or $37.1 \%$ of the total number of unemployed. The number of unemployed as compared to 2010 increased by $9.4 \%$ while they are unemployment rate in 2013 was $21.9 \%$. In the Central region, the number of unemployed persons at the end of 2013 amounted to 14.977 , or $43.4 \%$. The number of unemployed persons in 2013 increased by $3.8 \%$ compared to 2010. The unemployment rate in the central region at the end of 2013 amounted to $13.1 \%$. The number of unemployed in the Southern region at the end of 2013 totaled 6.727 , or $19.5 \%$ of the total number of unemployed in Montenegro. It is in the reporting period saw an increase in the number of unemployed to $14.0 \%$. The unemployment rate in the Southern region at the end of 2013 was 11.7\%. In the period 2010 - 2013 an increase was recorded the average number of employees in the central and coastal region, while in the North decline millet number of employees by $6.3 \%$, implying a further increase in the difference between the regions of Montenegro [65].

Analysis of income per capita is shown in Table 6 shows that the obvious differences between the regions in the minimum and maximum values of this indicator per capita. Thus, in 2013 per capita income was the lowest in the North region and amounted to euro 1.031.5, or two five times lower than in the central region (euro 2.233.8). When we look at budgetary revenues per capita by region, the lowest value was also recorded in the northern region (100.46 euro), which in 2013 was 5.7 times less than in the coastal region (572.99 euro). Indicator of unemployment and average unemployment rate, the highest in the Northern region and amounted to $21.9 \%$ in 2013 , while it was lowest in the Southern region and amounted to $11.7 \%$ and 1.87 times less than in the North region. According to most of the findings from the literature educational level was positively associated with pleasure and happiness (Ruff et al [70]; Kling and Wing [71]; Nezlek [72]; Markus et al [73]; Ryan and Huta [74]), which is logical given that a higher level of education an individual provides a greater range of opportunities and resources available. Indicator of education of the population of Montenegro is the largest in the Southern region, where the rate of education, according to data from the 2011 Census was $90 \%$ and was 1.27 times higher than in the North region (where it amounted to $71 \%$ ) [65].

Table 7. Number of MMS companies, entrepreneurs and employment for these categories, by region, in 2011-2013.

\begin{tabular}{|c|c|c|c|}
\hline Geospace & & 2011 & 2013 \\
\hline \multirow{3}{*}{ Northern } & MMS companies & 2.692 & 2.990 \\
\cline { 2 - 4 } & Number of employees & 16.615 & 19.201 \\
\cline { 2 - 4 } & Entrepreneurs & 3.752 & 4.005 \\
\hline \multirow{3}{*}{ Central } & MMS companies & 8.262 & 9.666 \\
\cline { 2 - 4 } & Number of employees & 53.720 & 65.535 \\
\cline { 2 - 4 } & Entrepreneurs & 4.731 & 5.606 \\
\hline \multirow{3}{*}{ Maritime } & MMS companies & 7.103 & 8.807 \\
\cline { 2 - 4 } & Number of employees & 36.244 & 49.854 \\
\cline { 2 - 4 } & Entrepreneurs & 5.342 & 6.288 \\
\hline \multirow{3}{*}{ Montenegro } & MMS companies & 18.057 & 21.463 \\
\cline { 2 - 4 } & Number of employees & 106.579 & 134.590 \\
\cline { 2 - 4 } & Entrepreneurs & 13.825 & 15.899 \\
\hline
\end{tabular}

Source: Ministry of Economy Government of Montenegro [65].

Some positive steps have been made in the sector of MMSP and entrepreneurship. According to the Tax Administration in the period 2011-2013 year can be seen growing trend in the number of MMSP, entrepreneurs, the number of employees in MMSP in all three regions, namely: Northern Region - 11.1\% more MMSP, 15.6 \% more employees and 6.7 \% more entrepreneurs; Central region 
- 17.0 \% more MMSP, 22.0 \% more employees and 18.5 \% more entrepreneurs; Coastal Region $24 \%$ more MMSP, 37.6 \% more employees and $17.7 \%$ more entrepreneurs. Based on the analysis of employment and unemployment in the regions, it can be concluded that current policies and incentives directed towards balanced regional development, especially in times of economic crisis, have not yielded effective results. Data on employment and unemployment, and demographic trends present a good basis for the Regional Development Strategy in the coming period, which will help to summarize the key priorities and measures for the realization of these priorities, in order to contribute to a larger achieving inclusive growth in the period up to 2020, which is an integral part of the issue of strengthening human resources and increasing employment and reducing unemployment [65].

According to Despotovic et al. [75] referring to the on studies Marković [76] and Vujošević [77] indicate that the data on the change of the participation of the agricultural population in the total population of Montenegro indicate its significant reduction in the reporting period. After 1945, as a result of the overall economic development and industrialization of the country, agricultural and general population in the mountainous area is reduced due to mass migration, so in 1961it accounts to about $60 \%$ of the total population. The process of increasing of non-agricultural and decreasing of agricultural population was also followed by the process of enlargement of urban and reduction of rural population. In comparison to the other republics of the former Yugoslavia, Montenegro in the period 1953-1971, recorded the highest growth of the urban population in relative terms.

According to Despotović et al [75] a sudden decrease in the participation of the agricultural population in the total population of Montenegro, at the same time it did not mean rapid increase in the active population. On the contrary, the percentage was very low throughout the post-war period and in 1953 it was 35.9 \% compared to the total population, or $65 \%$ compared to the population of working age. One of the greatest consequences of deagrarization in Montenegro is lack of labour force. The Montenegrin agriculture is characterized by aging of the rural population and significantly lower average level of education. More than $44 \%$ of them are older than 55 years, $65 \%$ are older than 45 . More than half (55.3\%) employed in agriculture had finished high school, and only $9.1 \%$ had completed higher school or university.

In the rural areas of Montenegro, due to uncontrolled development and the lack of adequate policy for these areas, the dynamics of living have been sluggish for decades. Villages have long been deteriorating. The liveliest inhabitants continually migrate and seek other places to fulfill their ambitions, make their living and start families. A higher standard of living has not been possible in rural settlements due to certain geostrategic, historical and other conditions. In this way, the rural areas were not valued; resources have been abandoned and become dead capital. The migration of the young persons, which is still happening, has caused a continuous degradation of these areas. It has also caused the urban areas to lose their rich surroundings. All these factors have further complicated the development process and caused a distinct disproportion in economic, demographic, cultural development etc. Both, everyday life and economic productivity have been disrupted in rural areas, making life there unviable for many [78].

Regions should become an economically developed union of local communities that are rich in democratic forms. It is in the interest of citizens to have good road infrastructure, good quality education, security and heath systems, a clean environment and so on. Ways of overcoming the inherited disproportions (demographic, economic, political, cultural and other) therefore need to be found so that more realistic conditions for more equal regional economic and, therefore, demographic development can be created; conditions for a decent life in those communities; for an easier flow of capital, goods and ideas, for encouraging entrepreneurship to through and for more a sustainable relationship with the nature [78].

One of the most are pressing problems that has for many years faced the world economy and society, but also Montenegro, the high unemployment rate. However, it seems that many issues related to this issue, and developments in the labor market in general, especially when it comes to the regional aspect of this issue is still insufficiently observed and empirically little explored. The intention to move closer to full membership of Montenegro in the European Union, which is now widely, both political and technical and scientific forums speaks and writes required to deal with this issue more attention and effort. The basic idea of the process of integration into the European Union is the introduction of the common market and the acceptance of European values 
in general. This would among other things, should contribute to and increase the mobility not only of capital but otherwise the state border cease to be a bigger problem, but also other factors of production such as labor mobility [79]. General economic theory teaches that in the conditions of market economy increased mobility of factors of production (capital, labor, and ideas) contributes to the increase of overall social efficiency. However, if these assumptions are exercised in practice in all situations, it is difficult to give an explicit answer. Studies conducted in many countries show that within each country there are parts of the territory (regions) which over a longer period recorded worse results, as measured by almost all major economic indicators including the level and the rate of unemployment and employment than the national average. It then, of course, adversely affects the overall socio-economic development of a country. If the mobility of factors of production is not developed at the national level, it is unlikely that it will significantly increase the expansion of the integration process and will; therefore, also benefit from the integration process will be lower than expected [79].

According to Beceu et al [80] by using the research World Commission on Environment and Development [81], Riberio and Remoaldo [82] and Bellamy et al [83] suggest that each region has its own characteristics and specific economic trends of development. The notion of region has evolved as a unit of innovation, economic growth and an appropriate scale to resolve the challenges of sustainable development. Imbalances between Montenegrin regions are a major issue which affects the national development. According to definition from the report "Our Common Future", "Sustainable development is development that meets the needs of the present generation without compromising the ability of future generation to meet their own needs". As Chai Ning and Dong Hoon [84] said, in order to meet continuous human needs, sustainable development has become the theme of today's world in different fields, and some renewable resources as tourism, should be continuously developed and utilized to contribute to the sustainable development. In the view of Berke [85] the sustainable development can be reached by a balance among the three 'E's: environment, economy and equity [80].

\section{Conclusion Remarks}

Our research evidence indicates the following important conclusions:

1. Regional Science has to do with territories analysis and development, approaching them on meson or micro scales, and it is a subject that has been attracting the interest of several disciplines, including Economics, Geography, Sociology, Engineering and Architecture. Evolution of Regional Science and derived since genesis between the end of the 1930s and 1950s until the 1970s, it evolved rapidly but, in the 80s it faced a crisis, as "thinking regionally" tended to be replaced by "thinking globally" and, because of this, spatial planning was largely abandoned. Another critical issue emerged by the end of the $20^{\text {th }}$ century. It came from the tendency by some within Regional Science toward emphasizing modeling and abstraction, instead of real problems of real regions. The social relevance of the research produced was, therefore, put in question [82].

2. Problems of regional development and regional disparities according to Čegar and Bogović [86] relying on research Dawkins [87], Boudeville [88] and Puljiz [43] indicate that they have been for a long time the focus of research carried out by economists, sociologists, geographers, and scientists from other fields of scientific research. How do the regions grow, why some grow faster than others, why there are regional disparities in the social and economic sphere; these are some of the central issues of regional development theories and regional policies? Literature provides many answers and reflections on key issues and factors of regional development [87]. For example, in the framework of the classical theory of economic development, regional growth and increase in regional disparities are explained by the growth poles i.e. location centers which attract investments and labour force from other areas due to their comparative and competitive advantages [88]. Much theoretical and empirical research that followed failed to offer an effective model of regional policy, which would ensure a long-lasting and continuous development of depressed or underdeveloped areas and reduce their development disparities. Although, for example, some studies referring to the entire European Union prove the presence of conditioned regional convergence, studies of regional differences in the new EU Member States indicate a significant increase in disparities (Poland, Hungary, Estonia). These results confirm that the process of EU accession and catching up with developed Member States is closely linked with increasing regional differences. These findings may be of great importance for Montenegro as the 
from candidate EU Member State, regarding the existing problems of significant regional disparities, and with respect to an adequate regional policy.

3. Combining global, national and local initiatives, there are literally hundreds of efforts to define appropriate indicators and to measure them [89], as these indicators must not only reflect changes in quality of life, but must also show if these changes are compatible with the planet's current ecological limits. Three of the most widely used indicators, recognized as relevant for measuring sustainable development, are: Human Development Index [90] as an indicator of development, Environmental Performance Index [91] as an indicator for environmental sustainability and Ecological Footprint [92] as an indicator of sustainable consumption. According to Mihaela [93] UN Human Development Index (HDI) provides an overview of human well-being, measuring development in terms of life expectancy, educational attainment and income and serves as a frame of reference for both social and economic development. The Environmental Performance Index (EPI), developed by Yale University and Columbia University, evaluates environmental sustainability relative to the paths of other countries, covering both environmental health and ecosystem vitality. Ecological Footprints a tool that measures our natural resource consumption and our global environmental impact, allowing us to work out whether there are enough resources in the world to sustain our activities. A large body of literature exists examining the strengths and shortcomings of the Ecological Footprint approach; yet despite acknowledged limitations, judging from the vast number of references, it remains a leading biophysical accounting tool for comparing present aggregate human demand on the biosphere with the Earth's gross ecological capacity to sustain human life.

4. There is no doubt that the issue of regionalization is today one of the most current theoretical and practical issues in Montenegro. The problem, however, is that it is not only in political but also in professional and scientific circles appear different, even diametrically opposite concept of regionalization. The issue of regionalization, in other words, he must put in a municipality sociological perspective of searching for answers to the question of how to reconcile the strong need of modern societies for homogeneity with an equally strong illegitimate their need for heterogeneity. This is even more so to remodeling company, which in some respects is becoming more heterogeneous in the other increasingly homogenous, it should be aimed at the establishment of a new type of integration, both at the intra society 'and the inter social areas [94]. In keeping with this approach, formerly an effort to define the basic criteria and indicators of "good" or "desirable" regionalization, such as: 1) that is based on the specific joint, but pluralistic characteristics clearly separated territorial units, formed less - more spontaneously in the long run; 2) that it contributes to the opening and not closing our own region, other territorial units, the whole society and its narrower and broader external environment; 3) that regionalization in the development of society and improve quality of life, to the region and the wider continent which he belongs and which is connected; 4) that the regionalization reduce or mitigate the existing social conflicts and preventing the emergence of new ones; 5 ) that regionalization establishes the rights necessary measures between centralization and decentralization desirable; 6) the regionalization give greater powers regional authorities as well as increased responsibility for their own development, as well as for the development of the whole society [94].

5. The territory of Montenegro covers a $13.812 \mathrm{~km}^{2}$, with a length of the coastline of 293.5 $\mathrm{km}$. When we look at the region, there is a great disparity in size, population and population density. The northern region extends to 52.8, Coastal Region at $11.6 \%$ of the territory of Montenegro. Population density in all three regions is uneven, so that the population is less in the northern part, in relation to the central and coastal region. The highest population density is in the coastal region ( $93.45 \mathrm{in} / \mathrm{km}^{2}$ ). Successful management of regional policy of the EU, as important forces of cohesion and economic integration between regions, based on the use of a range of indicators, most notably gross domestic product (GDP) per capita measured in purchasing power parity. In Montenegro, due to the lack of official data on gross domestic product at the level of local governments, it is not possible to analyze the share of local government units, or regions in the total GDP of Montenegro. In other words, it is not possible to determine which local governments are lagging behind the average development at the state level or above, as measured by GDP per capita PKS. However, in consideration of differences in regional development in Montenegro, are important indicators of regional differences, which are used as components in the calculation of the index of development [95]. 
6. Demographic aging is significantly marked the development of Montenegro's population over the last five decades. In the last analyzed period (2003 - 2011) on the part of the clearance level of demographic aging ("deep age"). In Montenegro, she performed mature post transition phase in the changes in age structure; marked by a contraction of the young population and the expansion of old, while reducing the number and proportion of working age population [96]. Such a balance among large age groups has many adverse consequences, especially come to the fore in the circumstances of underdevelopment and economic crisis. Analysis of future changes shows that in the next period to continue rapidly unfavorable demographic trends. It will continue to aging is interacting with the total depopulation [97]. There will be a further increase in the imbalance in the proportion of larger age groups; it is up to more pronounced inversion age "pyramid". This will lead to adverse changes in the components of natural population growth, as will the legality of demographic inertia affect the continued deterioration of the age structure of the population, or its aging. In order to slow down the aging process of the population of Montenegro and mitigate its effects, it is necessary to increase the birth rate, which would encourage the gradual rejuvenation of the population. So should press ahead with the implementation of an active policy of birth as the teaching part of the general development policy. The second group of measures relates to immigration, and the third to increase youth employment in order to prevent any more numerous emigration [97].

7. The problem of unemployment and employment is one of the most pressing socioeconomic problems of the modern world. However, all countries and regions are not equally affected by this issue. Even within each country there are parts of the territory (regions), which in the long period behind in the level of employment and record higher unemployment rates than the national average. One of the reasons for this phenomenon lies in the fact that the labor market has its own specific differences on the market of goods and capital, and may rightly say that this market is imperfect. Therefore, in the management regional development policy, both at EU level and in the framework of a large number of individual countries, special importance is given to finding adequate mechanisms and instruments that will contribute to the better functioning of labor markets, and thus to a more balanced regional development [79]. The labor market in Montenegro also characterized by sharp differences in is almost all levels of territorial belonging. The differences are especially pronounced among rural than in urban areas, south and central regions compared to the north, the concentration of labor resources both in scope and structure, as well as quality in large urban centers compared to other areas. The lack of timely and adequate measures of regional policy in the labor market has resulted in that the peripheral areas remained virtually without human resources who possess entrepreneurial initiative and the appropriate qualifications and other characteristics required by modern industrial mode of production, which may be carriers of their rapid development and progress in the future[79].

8. Montenegro is committed to join the developed countries in Europe and to attempt zest the include in their development, but in that their effort she has a huge backlog in terms of economic, technological, administrative and human resources, as well as most of the former socialist countries. For its part, the European Union has developed methodology for acceptance of these countries, which has the task to prevent the destruction of the economies of these countries, but on the other hand to enable these countries rapid development and gradually strengthening the competitiveness of their economies, and within them and their regional development [98].

9. Future development of Montenegro has to be adjusted to the capacities of the environment, which in other words means that the economic policies must obey the principles of sustainability. Future business models will have to apply only those modern technologies which will not put undue strain on the environment. Strategic directions of the future economic, scientific, technological, social and cultural development must fulfill the needs of future generations by developing its economic base, improving human resources and standard of living, identifying developing projects and their potential, but at the same time focusing on the necessary infrastructure- water, power supply, waste water, telecommunication as well as education, local institutions and so on.. Experiences of other European development policies are always useful and irreplaceable. Montenegro's future depends on its commitment to revitalizing its rural areas and overcoming regional disparities [78; see 99; 100].

The role of the village must be first-rate, because its potential future main development forces regional geospace Montenegro. This requires a radically new relationship between society 
and science for the regional development. It must be developed a new concept, integrated rural development, which will be based on demographic, natural, economic and socio-cultural resources. Responsible role in the design and concept of a geographical and science, its holistic approach should integrate research efforts and the results of other scientific disciplines [see 101,102,103,104,105].

\section{References:}

1. B. Derić, B. Atanacković, Concept of regional development of Serbia, in: Regional Development and Demographic Trends of the Balkan countries, Niš: Faculty of Economics. 5 (2000) 53-65.

2. B. Derić, D. Perišić, Criteria of regionalization of Serbia's territory, in: Spatial planning, regional development and environmental protection, (ed. D. Perišić), Belgrade: Institute for Architecture and Urban Planning. 28(1996) 11-18.

3. V. Rogić, Geographical aspect region, Geografski glasnik. 25(1963) 113-120.

4. W. R. Thompson, The regional subsystem: a conceptual explication and a propositional inventory, International Studies Quarterly.(1973) 89-117.

5. M. Foucault, Space, Knowledge, and Power, In Foucault Reader, ed. by Rabinow, Paul, 239-256. New York: Pantheon Books, 1984.

6. R. J. Searle, The Construction of Social Reality, New York: The Free Press, 1995.

7. B. Hettne, Development, security and world order: a regionalist approach, The European Journal of Development Research. 9(1)(1997) 83-106.

8. E. Zaretsky, Identity Theory, Identity Politics: Psychoanalysis, Marxism, PostStructuralism. In: Social Theory and the Politics of Identity, edited by Calhoun, Craig, 198-215. Oxford: Blackwell Publishing, 1998.

9. D.E.Mansfield, V.H. Milner, The new wave of regionalism, International organization. 53(03)(1999) 589-627.

10. M. Castells, Rise of the networked society, Zagreb: Golden Marketing,200o.

11. P.Milenković, Boundaries of the region: Heterotopias and identity, The epistemological aspect, Sociološki pregled. 36(1-2)(2002) 201-217.

12. A. Lupel, Regionalism and Globalization: Post-Nation or Extended Nation? Polity 36 (2)(2004) 153-174.

13. J.Todd, Social Transformation, Collective Categories, and Identity Change, Theory and Society. 34(4)(2005) 429-463.

14. H.Grad, M.L. Rojo, Identities in discourse - An integrative view. In Analysing Identities in Discourse, edited by Dolón, Rosana and Todolí, Júlia, pp. 3 Amsterdam / Philadelphia: JohnBenjamin's Publishing Company, 2008.

15. J.Harrison, The region in political economy, Geography Compass. 2(3)(2008) 814-830.

16. K.Ž.Ruano - Borbalan, The construction of identity, identity on (and) - individual, group, society, prepared Halpern, Katrin and Ruano-Borbalan, Žan-Klod, pp. 5-16, Belgrade: Clio, 2009.

17. B.I.Nojman, Meaning, Materiality, Power: Introduction to Discourse Analysis, Belgrade: Centre for Civil-Military Relations, Alexandria Press, 2009.

18. A.Turen, New paradigm - for a better understanding of contemporary society, Belgrade: Official Gazette. Jonas, A. E., (2012), Region and place Regionalism in question, Progress in Human Geography. 36(2)(2011) 263-272.

19. E.A.Jonas, Region and place Regionalism in question, Progress in Human Geography. 36(2)(2012) 263-272.

20. A.J.Agnew, Arguing with regions, Regional Studies. 47(1)(2013) 6-17.

21. E.A.Jonas, City-regionalism as a contingent 'geopolitics of capitalism', Geopolitics. 18(2)(2013)284-298.

22. S. Déry, W. Leimgruber, W. Zsilincsar, Understanding marginality: recent insights from a geographical perspective, Hrvatski geografski Glasnik. 74(1)(2012) 5-18.

23. B.I.Nojman, Using another - "East" in the formation of European identity, Belgrade: Official Gazette, Belgrade: Center for Security Policy, 2011.

24. M.Klemenčić, Atlas Europe, Lexicographic Institute "Miroslav Krleža", Zagreb, Chapter: Region, regionalization and regionalism, 1997. 
25. A.Fedajev, R. Nikolić, The concepts methods and measurement of EU regional development, Economics management information technology. 1(1)(2012)48-57.

26. G. Ilić Gasmi, EU Reforms - Institutional Aspects, IGP "Prometej", Belgrade, 2004.

27. V. Međak, S. Majstorović, EU regional policy, the Government of the Republic of Serbia, the Office for European Integration, Belgrade, 2004.

28. D.Lajh, The common cohesion policy and multilevel decision-making in the EU, Politička misao. XLIII (2006) 3-24.

29. M.Boesch, Engagierte Geographie; Erkundliches Wisen, Heft 98,Steiner Verlag,1989. 1981.

30. K.Ruppert, F. Schaffer, J. Maier, R. Paesler, Social geography, Zagreb: Školska knjiga,

31. M.Antić Slukan, Croatia in European Regionalization: Regionalization as Integration or Geography of Power, Društvena istraživanja. 3(95)(2008) 351-372.

32. ] M.Vasović, Another attempt at regionalization of Serbia, Journal of the Geographical Institute Faculty of Sciences. 12 (1965).

33. B.Piha, Basis of Spatial Planning, Belgrade: Economic - financial guide, 1979.

34. R.Väyrynen, Regionalism: Old and New, International Studies Review. 5(1)(2003) 25-51.

35. M.Fujita, The development of regional integration in East Asia: From the viewpoint of spatial economics, Review of urban \& regional development studies. 19(1)(2007) 2-20.

36. B.Stojkov, Processes of regionalization in the countries of Central, Eastern and Southeastern Europe, Glasnik Srpskog geografskog društva. LXXXII (1)(2000) 59-82.

37. M.Maksin-Mićić, S. Milijić, M. Nenković-Riznić, Spatial and environmental planning of sustainable regional development in Serbia, Spatium. 21(2009) 39-52.

38. M.R.Milanović, V. Radojević, G. Škatarić, Depopulation as a factor of rural and regional development in Montenegro, Škola biznisa. 4(2010) 32-40.

39. M.Tripković, Regionalization in Serbia: Between centralism and regionalism, Sociološki pregled. XXXVI (1-2)(2003) 33-48.

40. G.Rajović, J. Bulatović, Life as a geographical theme - one more contribution to the study of quality of life, World Scientific News.28(2016) 41-57.

41. G. Rajović, J. Bulatović, Different attitudes toward the quality of life concept, Azerbaijanian Journal of Economics and Social Studies. 4(2015) 70 - 93.

42. E. Klima, A. Janiszewska, S. Mordwa, Elderly people and their quality of life - challenges for geography, Space-Society-Economy. 13(2014) 173-189.

43. J. Puljiz, Theories of regional development in the economic literature, TITIUS Yearbook: Yearbook for Interdisciplinary Research of the Krka River Basin. 3(3)(2011) 63-82.

44. P.Krugman, What's new about New economic Geography?, Oxford Review of Economic Policy. 14(2)(1998) 7-17.

45. M. Fujita, T. Mori, Frontiers of the New Economic Geography, Discussion paper no. 27, Institute of Developing Economies, 2005.

46. E. Sima, Impact of organic farming promotion upon the sustainable rural development, Agricultural Economics and Rural Development, New Series. Year VI(2)(2009)217-233.

47. I.Rosić, P. Veselinović, National economy, Kragujevac: Faculty of Economics, 2006.

48. R.Tiosavljević, Regional Development and Serbia's policy, Regional Development and Demographic Trends of Southeast Europe, Niš: Faculty of Economics, 2010.

49. L.D.Constantin, Regional science research in Romania through the lens of the first ten conferences of the Roamnian regional science association, Revista Brasileira de Gestão e Desenvolvimento Regional. 11(4)(2015)37-50.

50. L.D.Constantin, The Past and Future of Regional Science, Scienze Regionali. 6 (2)(2007)147-150.

51. L.D.Constantin, Future Challenges to Regional Science. Highlights for Research in Central and East European Countries, in I. Palne-Kovacs, J. Scott, Z. Gall (Eds), Territorial Cohesion in Europe, Hungarian Academy of Sciences, IRS-CERS, Pecs, pp. 208-218(2013).

52. F. Just, Rural-Urban interlinkages and regional development, Studies on the Agricultural and Food Sector in Central and Eastern Europe. 39(2007)3-17.

53. J.Janičić, M. Laketa, S. Vukotić, Investment policy and regional development of Serbia in the transitional period, Zbornik Geografskog institute"Jovan Cvijić” SANU. 61(3)(2011) 47-61. 
54. V.Čavrak, Strategy and policy of regional development Croatian, Economics. 9(34)(2002) 645.

55. E. Jakopin, A. Perišić, Regional Development, Belgrade: Faculty of Economics, Finance and Administration $\left.{ }^{* * *}\right)$.

56. M. Vujović, Creating a new model of financing regional development, Available from: http:// www.aktivna.org (31.10.2015).

57. M. Andrews Frank, B. Withey Stephen, Social Indicators of Well-Being: Americans Perception of Life Quality, New York: Plenum,1976.

58. D.Watson, A.L. Clark, A. Tellegen, Development and validation of brief measures of positive and negative affect: the PANAS scales, Journal of personality and social psychology. 54(6)(1998) 1063.

59. J. Van Oudenhoven, P. Willemsen, Ethnic Minorities: Social Psychological Perspectives (Tinke M.(ed.), Amsterdam: Swets \& Zeitlinger,1989. 75-91.

6o. J. Stojilković, Baby boom generation at the retirement onset, Stanovnistvo. 48(2)(2010)

61. D.Ryff Carol, J. Magee William, C. Kling Kristen, H. Wing Edward, Forging macro-micro linkages in the study of psychological well-being, in: C. D. Ryff and V. Marshall (ed.), The Self and Society in an Aging Process, New York: Springer, pp. 247-278 (1999).

62. K. Wahl Astrid, T. RustØen, R. Hanestad Berit, A. Lerdal, T. Moum, Quality of life in the general Norwegian population, measured by the Quality of Life Scale (QOLS-N), Quality of life research. 13(5)(2004) 1001-1009.

63. L. Lima Maria, R. Novo, So far so good? Subjective and social well-being in Portugal and Europe, Portuguese Journal of Social Science. 5(1)(2006) 5-33.

64. I. Lučev, M. Tadinac, The Quality of Life in Croatia-the Connection between Subjective and Objective Indicators as well as Temperament and Demographic Variables with a Reference to Minority Status, Migracijske i etničke teme . 24(1-2)(2008) 67-89.

65. Ministry of Economy Government of Montenegro, Regional Development Strategy of Montenegro for the period 2014-2020, Government of Montenegro, Podgorica, 2008.

66. N.Keyfitz, On the Momentum on Population Growth, Demography. 8 (1)(1971) 222-234.

67. PRB, World Population Dana Sheet, Population Reference Bureau, Inc, Washington, 2012.

68. C.J.Chesnais, The inversion of the Age Pyramid and the Future of Population Decline, UNDP, Expert Group Meeting on Polycy Responses to Population Ageing, New York (2000).

69. Statistical Office of Montenegro - Monstat, Communication No. 68, Podgorica, 2014.

70. D.Ryff Carol, J. Magee William, C. Kling Kristen, H. Wing Edward, Forging macro-micro linkages in the study of psychological well-being, in: C. D. Ryff and V. Marshall (ed.), The Self and Society in an Aging Process, New York: Springer, pp. 247-278 (1999).

71. C.K. Kling, H.E. Wing, Forging Macro-Micro Linkages in the Study of Psychological WellBeing, The Self and Society in Aging Processes. 247 (1999).

72. B.J.Nezlek, The motivational and cognitive dynamics of day-to-day social life, the social mind: Cognitive and motivational aspects of interpersonal behavior. (2000) 92-111.

73. R.H. Markus, D.C. Ryff, B.K. Curhan, A.K. Palmersheim, In their own words: Well-being at midlife among high school-educated and college-educated adults, How healthy are we.(2004) 273-319.

74. M.R. Ryan, V. Huta, Wellness as healthy functioning or wellness as happiness: The importance of eudemonic thinking (response to the Kashdan et al. and Waterman discussion), The Journal of Positive Psychology. 4(3)(2009) 202-204.

75. A. Despotović, M. Joksimović, M. Jovanović, Impact of demographic changes on agricultural development in Montenegro, Economics of Agriculture. 3(2015) 613-625.

76. P. Marković, Changes in economic and social structure of the population and labour force of mountainous regions of Yugoslavia, Agriculture and Forestry. 20(4)(1974) 89.

77. N. Vujošević, Changes in the rural family in Montenegro, SANU, Belgrade-Nikšić, Book DLXXXVII, 92-95(1990).

78. J. Radulović, The problems of regional development in Montenegro, Applied Studies in Agribusiness and Commerce, Scientific Papers. (2014) 85-88. 
79. V. Radovanović, M. Maksimović, Labor market and (un) employment in the European Union and Serbia: Regional aspects, Journal of the Geographical Institute Jovan Cvijic, SASA. $60(2)(2010)$ 59-75.

8o. S. Beciu, G.R. Lădaru, Sustainable Regional Development: Approches for the North East Region-Romania, Journal of Eastern Europe Research in Business \& Economics. 2014(2014) 1-9.

81. World Commission on Environment and Development, Our common future, Oxford, UK, Oxford University Press, 1987.

82. J. C. Riberio, P. Remoaldo, Portuguese publication in the aim of regional sciences: a study of articles published in riper from 2003 to 2005, Revista Brasileira de Gestão e Desenvolvimento Regional. 11(4)(2015)3-26.

83. J. Bellamy, T. Meppem, R. Goddard, S. Dawson, The changing face of regional governance for economic development: implications for local government, Sustaining Regions. 2 (3)(2003) 7-17.

84. Chai Ning, Dong Hoon, Sustainable development strategy of tourism resources offered by regional advantage: Exploring the fesability of developping an "exotic culture" resource for Weihai City of China, Procedia engineering. 21(2011) 543-552.

85. R.P. Berke, Does sustainable development offers a new direction for planning? Challanges for the twenty - first century, Journal of Planning Literature. 17(1)(2002) 21-36.

86. S. Cegar, D.N. Bogović, Economic Characteristics and Developmental Prospects of East Croatia, In 4th International Scientific Symposium Economy eastern Croatian-vision and development, and Croatian scientific bibliography MZOS - Svibor, 2015.

87. J.C. Dawkins, Regional Development Theory: Conceptual Foundations, Classic Works and Recent Developments, Journal of Planning Literature. 18(2)(2003) 131-172.

88. R. J. Boudeville, Problems of Regional Economic Planning, Edinburgh: University Press, 1996.

89. T. Parris, R. Kates, Characterizing and Measuring Sustainable Development, Annual Reviews of Environment and Resources. 28 (2003) 559- 86.

90. UNDP, The 2011 Human Development Report, Available from: http://hdr.undp.org (25.11.2015).

91. Yale University and Columbia University, Environmental Performance Index and Pilot Trend Environmental Performance Index"(2012). Available from: http://epi.yale.edu (26.11.2015).

92. Global Footprint Network, Ecological Footprint Atlas(2010). Available from: http://www.footprintnetwork.org (27.11.2015).

93. K.Mihaela, Romania on the path to sustainable development, Comparative analysis within the European Union, Annals of Faculty of Economics,. 1(2)(2012) 100-106.

94. M. Tripković, Regionalization and multiculturalism in sociological perspective, Sociološki pregled. 1-2(2002) 5-16.

95. Ministry of Economy Government of Montenegro, Regional Development Strategy of Montenegro for the period 2010 -2014, Government of Montenegro, Podgorica(2011).

96. G. Rajović, J. Bulatović, Demographic Processes and Trends: The Case of Region Polimlje-Ibar, International Letters of Social and Humanistic Sciences. 63(2015) 63 - 75 .

97. I. Nejašmić, A. Toskić, Ageing of the Population in Croatia-the Current Situation and Perspectives, Hrvatski geografski Glasnik. 75(1)(2013) 89-110.

98. M. Mirković, Integrated rural development as a factor in poverty reduction, Ekonomski pogledi. 1(2010) 45-54.

99. G. Rajović, J. Bulatović, Demographic processes and trends: the case of northeastern Montenegro, Russian Journal of Agricultural and Socio - Economic Sciences. 3 ( 51) 14 - 29.

100. G. Rajović, J. Bulatović, Quality of life in rural villages of Montenegro - Gnjili Potok and Vranještica: Case study, Scientific Electronic Archives. 9 (2) (2016) 23 - 35.

101. G. Rajović, J. Bulatović, Traffic Infrastructure as Precondition Development Tourism on the Mountain Katuns: Example of Municipality Andrijevica, European Journal of Social and Human Sciences. 7(3)(2015) 150-162.

102. G. Rajović, J. Bulatović, Plant and Animal production in Montenegro with Overview of

the Food Industry, International Letters of Social and Humanistic Sciences. 63(2015) 7 - 16.

103. G. Rajović, J. Bulatović, Some Demographic Changes in the Population of Montenegro with the Projection of Future Demographic Development, Journal of Advocacy, Research and Education. 5 (1) (2016) $23-28$. 
104. G. Rajović, J. Bulatović, Review on Demographic Changes in the Agricultural Population of Montenegro, the Structure of Agricultural Land and Economic Development, Наука. Мысль. 4(2016) 181-188.

105. G. Rajović, J. Bulatović, Regional Aspects of the Population in Montenegro: Review, Population Processes, 1(1)(2016) $27-34$.

УДК 33

\title{
От концепции региона к имиджу Черногории From Concept of the Region to Regional Image of Montenegro
}

\author{
${ }^{1}$ Горан Райович \\ 2 Джелисавка Булатович
}

\begin{abstract}
${ }^{1}$ Международный сетевой центр фундаментальных и прикладных исследований, Российская Федерация

E-mail address: dkgoran.rajovic@gmail.com

${ }^{2}$ Колледж текстильного дизайна, технологии и управления, Белград, Сербия

E-mail address: jelisavka.bulatovic@gmail.com
\end{abstract}

Аннотация. Основное направление работы - понимание проблемы регионального развития, что в последнее время становится все более важной социально-экономической проблемой. Проблемы регионального развития Черногории на протяжении более полувека не имеют достаточной теоретической и практической основы. Новые современные модели экономического роста и развития основываются на секторальных приоритетах и стратегиях, краткосрочных и среднесрочных целях. Для того чтобы замедлить процесс старения населения в Черногории и смягчить его последствия, надо увеличивать рождаемость, что будет способствовать постепенному омоложению населения. Вторая группа мер относится к иммиграции, а третья направлена на повышение занятости молодежи во избежание более многочисленной эмиграции. Проблема занятости и безработицы является одной из самых социально-экономических проблем в Черногории. Поэтому в управлении по развитию региональной политики на уровне ЕC, особое значение приобретает поиск адекватных механизмов и инструментов, которые будут способствовать улучшению функционирования рынков труда, и, следовательно, более сбалансированному региональному развитию. В Черногории необходимо разработать новую концепцию комплексного регионального развития, которое будет опираться на демографические, природные, экономические и социально-культурные ресурсы.

Ключевые слова: Черногория, регионы, региональное развитие, демографические показатели, показатели социально-экономического развития (занятость и безработица). 